(Knox, 1966) and provide a firmer base for decision on longterm planning and development. Thus whatever approach is made to immediate provision of services, the more intensive local study of communities large enough to produce definitive answers (Lawson, 1966) remains an essential component of any general screening programme.

\section{* Summary}

Comparison has been made between biochemical (6-phosphogluconate dehydrogenase activity) and cytological methods of cervical screening in a survey of 4,385 married women attending hospital and general practice clinics. The survey detected 28 cases of carcinoma-in-situ, an overall yield of 6.4 per 1,000. Among the 27 patients for whom enzyme assessment was available, $21(78 \%)$ had at least one result showing an enzyme activity of less than 100 units/g. dried weight. Among 15 carcinoma-in-situ patients with more than one enzyme result, $10(67 \%)$ were consistently negative by the same standard. With such a high proportion of false-negative results the enzyme test, as at present developed, cannot be regarded as a practical alternative to cytology for detecting preinvasive cervical cancer.

The study's experience of general practice clinics confirmed the contrast between popular demand for cervical screening and the relatively low acceptance rate when this service is offered freely. Less than half of the women eligible attended the clinics. Study of response and prevalence rates from individual practices in relation to their respective social class distribution supported the view that acceptance of screening is lowest among the less health-conscious women at greatest risk, and that this differential response represents a major problem in the development of any effective comprehensive service. The more optimistic hopes for such a service have yet to be realized, and, whatever approach is made to immediate provision of screening facilities, doubts and uncertainties which remain point to the need for supplementing any general programme with more intensive population studies at a local level.

We are pleased to acknowledge the co-operation and help of the general practitioners and gynaecologists who granted facilities for the survey. In particular we are indebted to the late Professor W. C. W. Nixon, Mr. J. D. S. Flew, Mr. J. M. Holmes, and Drs. H. C. Faulkner, D. M. Grant, M. J. F. Gilchrist, R. D'Arcy Hart, J. P. Horder, E. J. Horder, H. N. Levitt, D. M. Miller, M. Modell, A. H. Pote, C. A. Steen, and J. W. Wigg.

Sister D. Pracy assisted at the screening clinics, and Mrs. E. Goldenberg, Miss C. M. Jones, and Miss K. M. Jones undertook patient-interviews and follow-ups. Our thanks are due to them and to the many other members of hospital, practice, and unit staff who provided technical and other assistance. Part of the cost of this investigation was borne by the Ministry of Health.

\section{REPERENCES}

Ashley, D. J. B. (1966a). 7. Obstet. Gynaec. Brit. Cwlth, 73, 372 (1966b). Ibid., 73, 382.

Bell, J. L., and Egerton, M. E. (1965). Ibid., 72, 603

Bell, J. L., and Egerton, M. E. (1965). 1 . B., Brit. med. 7., 2, 823.

Boyes, D. A., Fidler, H. K., and Lock, D. R. (1962). Ibid., 1, 203. Brit. med. Ұ., 1965, 1, 1327.

Bryans, F. E., Boyes, D. A., and Fidler, H. K. (1964). Amer. F. Obstet. Gynec., 88, 898 .

Cameron, C. B., and Husain, O. A. N. (1965). Brit. med. 7., 1, 1529.

and Weg, M. W. (1964). In Proceedings of Technicon International Symposium, London

Chayen, J., Bitensky, L., Aves, E. K., Jones, G. R. N., Silcox, A. A., and Cunningham, G. J. (1962). Nature (Lond.), 195, 714.

Jeffcoate, T. N. A. (1966). Brit. med. 7., 2, 1091.

Jeffcoate, T. N. A. (1966). C. Mrit. med. (1965)." Lancet, i, 543.

Jones, A. E., and Brown, C. M. (1965). Lancet, 1, 543 . by G. McLachlan. London.

Lawson, J. G. (1966). Brit. med. 7., 2, 1260.

and Watkins, D. K. (1965). Ұ. Obstet. Gynaec. Brit. Cwlth, 72, 1. Macgregor, J. E., and Baird, D. (1963). Brit. med. F., 1, 1631 Muir, G. G., Canti, G., and Williams, D. (1964). Ibid., 2, 1563. Petersen, O."(1955). Acta radiol. (Stockh.), Suppl. No. 127.

Petersen, O. M. G. (1965). Mth. Bull. Minist. Hlth Lab. Serv., 24, 72.

Younge, P. A (1965). F. Obstet. Gynaec. Brit. Cwlth, 72, 9.

Yule, R., and Cameron, F. H. D. (1961). Ibid., 68, 658.

\title{
Isoniazid Therapy in Relation to Later Occurrence of Cancer in Adults and in Infants
}

\author{
E. CUYLER HAMMOND,* SC.D. ; IRVING J. SELIKOFF,† M.D. ; EDWARD H. ROBITZEK,‡ M.D.
}

Brit. med. F., 1967, 2, 792-795

This study was initiated as a result of a communication in the British Medical fournal by Roe, Boyland, and Haddow (1965), who pointed out that in the light of experimental evidence there was an urgent need for epidemiological studies on the possible carcinogenic effects of isoniazid therapy. More recently, similar sentiments were expressed in a strongly worded editorial in the Lancet (1966).

Difficulty with the epidemiological approach at this time lies in the fact that known carcinogenic agents rarely produce cancer in adult human beings until about 10 to 20 or more years after first exposure. Isoniazid was first administered experimentally to two men (I. J.S. and E. H. R.) in June 1951 and therapeutically to a sizable number of patients with tuberculosis at Sea View Hospital shortly thereafter (Selikoff, Robitzek, and Ornstein, 1952). Less than 16 years have elapsed since that time.

On the other hand, some carcinogenic chemicals act very rapidly when administered in utero to experimental animals (Druckrey, Ivanković, and Preussmann, 1966), and whatever factor or combinations of factors cause cancer in children must operate in a relatively short time. For example, in New York State in the period 1958-60 the highest incidence rate of childhood leukaemia (9.2 per 100,000 a year for males and females combined) occurred in 4-year-old children, and the rate was appreciable (3.7 per 100,000) even in 1-year-old children (Ferber, Handy, Gerhardt, and Solomon, 1962). For childhood cancer of all types and sites combined, the highest incidence rate $(16.4$ per 100,000$)$ occurred in 4-year-olds, but the rate was almost as high at ages 1,2 , and 3 years.

Since certain hormones have an influence on the growth rate of cancer, it is conceivable that pregnancy might enhance the potential carcinogenicity of isoniazid.

Over the years some authors have suggested that tuberculosis increases the risk of lung cancer, while others have suggested exactly the opposite. Further information on this point is pertinent to the problem at hand.

\footnotetext{
- Department of Epidemiology and Statistics of the American Cancer Society.

Department

$\ddagger$ Sea View Hospital, New York.
} 
For these reasons we have investigated cancer death rates in four groups of subjects: (1) men and women with a past history of tuberculosis, a small minority of whom may have received isoniazid; (2) patients with tuberculosis initially treated with isoniazid during the period October 1951 to September 1956 ; (3) women treated with isoniazid during pregnancy; and (4) the children resulting from these pregnancies.

\section{Subjects with History of Tuberculosis}

Between October 1959 and February 1960 volunteer workers of the American Cancer Society enrolled more than $1,000,000$ men and women, then over 30 years of age, in a prospective epidemiological study (Hammond, 1964a, 1964b). On enrolment, each subject filled out a lengthy confidential questionary. Over $98 \%$ of the subjects were traced up to 30 September 1964 and health departments provided copies of the death certificates of those who had died.

The questionary provided information on each subject in relation to past history of various diseases, including tuberculosis ; but it provided no information on isoniazid therapy. Altogether, 18,963 of the subjects, ranging in age from 30 to 89 , said that they had had tuberculosis. On the basis of data available to the Tuberculosis Program of the Communicable Disease Center of the U.S. Public Health Service, Shirley H. Ferebee (personal communication, 1967) estimated that 5 to $10 \%$ of them had probably received isoniazid. During the course of the study 1,297 of them died, 268 of the deaths being due to cancer. Of the 268 cancer deaths 45 were attributed to lung cancer. The remaining $1,011,006$ subjects had not to their knowledge had tuberculosis ; 57,935 of them died ; 12,981 of the deaths were due to cancer, and 1,848 of these were attributed to lung cancer.

The findings are summarized in Table I. The "observed" figures show the total number of cancer deaths and the number of lung cancer deaths which occurred among subjects with a history of tuberculosis. The "expected" figures show the number of cancer deaths which would have occurred had the rates for the tuberculosis group been exactly the same as the rates for the non-tuberculosis group, age and sex being taken into consideration. For men and women combined the observed and expected numbers of cancer deaths were very close (268 observed and 262.1 expected). For men the observed number was slightly greater than the expected number, while for women the observed number was slightly less than the expected number, but these differences are not statistically significant at the 0.05 level of confidence.

TABLE I.-Observed and Expected Number of Cancer Deaths Occurring Between the Autumn and Winter of 1959-60 and 30 September 1964 among 18,963 Subjects with a History of Tuberculosis. Expected Numbers are Based on the Records of 1,011,006 Subjects Who Did Not Have a History of Tuberculosis

\begin{tabular}{|c|c|c|c|}
\hline & Men & Women & Total \\
\hline $\begin{array}{l}\text { No. of subjects } \ldots \\
\text { No. of deaths from cancer (ail } \\
\text { sites): }\end{array}$ & 7,838 & 11,125 & 18,963 \\
\hline 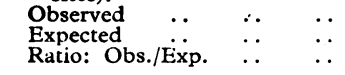 & $\begin{array}{r}144 \\
127 \cdot 9 \\
1.13\end{array}$ & $\begin{array}{l}124 \\
134 \cdot 2 \\
0 \cdot 92\end{array}$ & $\begin{array}{l}268 \\
262 \cdot 1 \\
1 \cdot 02\end{array}$ \\
\hline $\begin{array}{lccc}\text { No. of deaths from lung cancer: } \\
\text { Observed } & . & \ldots & \ldots \\
\text { Expected } & \ldots & \ldots & \ldots \\
\text { Ratio: Obs./Exp. } & \ldots & \ldots\end{array}$ & $\begin{array}{l}37 \\
30 \cdot 3 \\
1 \cdot 22\end{array}$ & $\begin{array}{l}8 \\
6 \cdot 2 \\
1 \cdot 29\end{array}$ & $\begin{array}{l}45 \\
36 \cdot 5 \\
1 \cdot 23\end{array}$ \\
\hline
\end{tabular}

For both men and women the observed number of lung cancer deaths was slightly larger than the expected number, but, being based on rather small numbers, the slight differences are not statistically significant at the 0.05 level of confidence. In this connexion it should be noted that the two groups of subjects (tuberculous and non-tuberculous) differed very little in their smoking habits.

\section{Isoniazid-treated Patients}

Between October 1951 and September 1956311 tuberculosis patients seen by two of us (I. J. S. and E. H. R.) in our private practices were treated with isoniazid and most of the survivors are still under our care. All of them lived in New Jersey or New York. In the spring of 1966 we started to trace those who were no longer under our care. Whenever possible we obtained reports from their present physicians, but in some cases we had to depend on statements made in telephone calls or letters from the patients or their relatives. For the purpose of this report we have used 1 June 1966 as a cut-off date. That is, we have not used any information collected since that time, because it is incomplete.

In treating the patients we used a standard daily dosage of $4 \mathrm{mg}$. of isoniazid per $\mathrm{kg}$. of body weight. Of the 311 patients, 55 were treated for less than one year, 97 for one to two years, 87 for two to three years, 29 for three to four years, 11 for four to five years, 9 for five to six years, and 20 for six years or longer. The duration of therapy is uncertain for the remaining 3 cases.

Table II shows the age and sex distribution of the patients at the date of first treatment with isoniazid and their status at 1 June 1966. The eight subjects not traced in 1966 were alive with no evidence of cancer when last seen by us. Table III shows the distribution of the patients classified by the length TABLE II.-Age and Sex Distribution and Status at 1 fune 1966 of 311
Tuberculosis Patients First Treated with Isoniazid Between October 1951 and September 1956

\begin{tabular}{|c|c|c|c|c|c|}
\hline \multirow{2}{*}{$\begin{array}{l}\text { Age at First } \\
\text { Isoniazid } \\
\text { Exposure }\end{array}$} & \multirow{2}{*}{ Total } & \multicolumn{3}{|c|}{ Status at 1 June 1966} & \multirow{2}{*}{$\begin{array}{l}\text { Died } \\
\text { of } \\
\text { Cancer }\end{array}$} \\
\hline & & Alive & Dead & Unknown & \\
\hline \multicolumn{6}{|c|}{ Males } \\
\hline $\begin{array}{l}<20 \\
20-29 \\
30-39 \\
40-49 \\
50-59 \\
60+\end{array}$ & $\begin{array}{r}7 \\
27 \\
36 \\
41 \\
18 \\
16 \\
\end{array}$ & $\begin{array}{r}6 \\
25 \\
26 \\
31 \\
8 \\
9\end{array}$ & $\begin{array}{r}1 \\
1 \\
8 \\
7 \\
10 \\
7\end{array}$ & $\begin{array}{l}-1 \\
2 \\
3 \\
-\end{array}$ & $\begin{array}{c}- \\
1 \\
4 \\
2 \\
2\end{array}$ \\
\hline Total & 145 & 105 & 31 & 6 & 9 \\
\hline \multicolumn{6}{|c|}{ Females } \\
\hline $\begin{array}{l}<20 \\
20-29 \\
30-39 \\
40-49 \\
50-59 \\
60+\end{array}$ & $\begin{array}{r}10 \\
64 \\
46 \\
31 \\
9 \\
6\end{array}$ & $\begin{array}{r}9 \\
59 \\
41 \\
24 \\
9 \\
5\end{array}$ & $\begin{array}{l}\overline{5} \\
4 \\
7 \\
1\end{array}$ & $\begin{array}{l}1 \\
-1 \\
- \\
-\end{array}$ & $\begin{array}{l}\bar{z} \\
\overline{(1)} \\
\overline{-}\end{array}$ \\
\hline Total & 166 & 147 & 17 & 2 & $(1)^{*}$ \\
\hline Grand total & 311 & 252 & 51 & 8 & $10 t$ \\
\hline
\end{tabular}

* Possibly died of cancer, diagnosis in doubt. + Includes one doubtful case.

TABLB III.-Years from Date of Initial Isoniazid Therapy to Date of Death or Date Last Known to be Alive and Status at 1 fune 1966 of 311 Tuberculosis Patients First Treated with Isoniazid Betwoen October 1951 and September 1956.

\begin{tabular}{|c|c|c|c|c|c|}
\hline \multirow{2}{*}{$\begin{array}{c}\text { Years } \\
\text { Traced }\end{array}$} & \multirow{2}{*}{ Total } & \multicolumn{3}{|c|}{ Status at 1 June 1966} & \multirow{2}{*}{$\begin{array}{c}\text { Died } \\
\text { of } \\
\text { Cancer }\end{array}$} \\
\hline & & Alive & Dead & Unknown & \\
\hline \multicolumn{6}{|c|}{ Males } \\
\hline $\begin{array}{l}55 \\
5 \text { to } 10 \\
10 \text { to } 11 \\
11 \text { to } 12 \\
12 \text { to } 13 \\
13 \text { to } 14 \\
14+\end{array}$ & $\begin{array}{r}14 \\
27 \\
14 \\
20 \\
33 \\
28 \\
9 \\
\end{array}$ & $\begin{array}{r}7 \\
12 \\
18 \\
33 \\
27 \\
8\end{array}$ & $\begin{array}{r}10 \\
18 \\
2 \\
2 \\
1 \\
1 \\
1\end{array}$ & $\begin{array}{l}4 \\
2 \\
= \\
= \\
=\end{array}$ & $\begin{array}{l}\frac{1}{6} \\
\frac{2}{2} \\
=\end{array}$ \\
\hline Total & 145 & 105 & 34 & 6 & 9 \\
\hline
\end{tabular}

\begin{tabular}{|c|c|c|c|c|c|}
\hline $\begin{array}{c}<5 \\
5 \text { to } 10 \\
10 \text { to } 11 \\
11 \text { to } 12 \\
12 \text { to } 13 \\
13 \text { to } 14 \\
14+\end{array}$ & $\begin{array}{r}6 \\
17 \\
23 \\
26 \\
33 \\
37 \\
24\end{array}$ & $\begin{array}{l}7 \\
22 \\
25 \\
33 \\
36 \\
24\end{array}$ & $\begin{array}{r}5 \\
9 \\
1 \\
1 \\
-1 \\
-\end{array}$ & $\begin{array}{l}1 \\
1 \\
- \\
= \\
=\end{array}$ & $\begin{array}{l}\overline{(1)} \\
= \\
= \\
=\end{array}$ \\
\hline Total & 166 & 147 & 17 & 2 & (1) \\
\hline Grand total & 311 & 252 & 51 & 8 & $10+$ \\
\hline
\end{tabular}


of time between first exposure to isoniazid and the date of death or the date when last traced alive.

Altogether 51 subjects ( 34 males and 17 females) are known to have died. Three men died of bronchogenic carcinoma, one of larynx cancer, one of pharynx cancer, one of bladder cancer, one of chronic myelogenous leukaemia, and one of metastatic liver cancer which probably originated in a gastrointestinal site. One man died in 1955 in another part of the country; his sister, a trained nurse, said that he died of lung cancer. The sister has since died, and we have been unable to obtain any further information on this case; for purposes of this report we will assume that the man "probably" died of lung cancer. One woman died with a hilar density suggesting tumour, and death may have been due either to brain metastasis or to cerebral vascular accident. Hereafter we will refer to the death as " possibly due to cancer." Thus, all told, 8 of the 51 deaths were definitely due to cancer, 1 was probably due to cancer, and 1 was possibly due to cancer. Of the remaining 41 deaths, 17 were due to tuberculosis or conditions apparently resulting from tuberculosis (pulmonary haemorrhage, pulmonary insufficiency, bronchopleural fistula, cor pulmonale, etc.), 8 died of heart diseases, 4 of cerebral vascular accidents, 4 of violence or accidents, 2 of cirrhosis of the liver with alcoholism, 1 of asthma, 1 of pulmonary embolism, 1 of amyloidosis, 1 of uraemia, 1 of hepatitis, and 1 of unknown cause.

Table IV shows the observed and expected number of cancer deaths in two periods of time: (1) the first seven years following the initial administration of isoniazid, and (2) later years. For each of these two periods of time we computed person-years of exposure to risk by single years of attained age for males and females separately. To the person-years so computed we applied the age-specific rates of death from cancer as reported for the male and female populations of New Jersey and New York State in the census year 1960. This provided us with estimates of the "expected" numbers of cancer deaths under the null hypothesis that isoniazid-treated tuberculosis patients do not differ in this respect from the general population of New Jersey and New York. Cancer death rates (cancer of all sites combined) are somewhat higher in these two States than in the United States as a whole.

TABLE IV.-Observed and Expected Number of Deaths Due to Cancer Among 311 Tuberculosis Patients Initially Treated with Isoniazid Between October 1951 and September 1956 and Traced up to 1 fune 1966. Expected Numbers are Based on Cancer Death Rates Reported for the States of New Fersey and New York

\begin{tabular}{|c|c|c|c|c|c|}
\hline \multirow{2}{*}{\multicolumn{4}{|c|}{ Period }} & \multicolumn{2}{|c|}{ No. of Deaths Due to Cancer } \\
\hline & & & & Observed & Expected \\
\hline \multicolumn{6}{|c|}{ Males } \\
\hline $\begin{array}{l}\text { First } 7 \text { years } \\
\text { After } 7 \text {, }\end{array}$ & . & 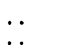 & . & $\frac{4}{5}$ & $\begin{array}{l}2 \cdot 1 \\
1.9\end{array}$ \\
\hline & Total & $\cdots$ & $\cdots$ & 9 & $4 \cdot 0$ \\
\hline \multicolumn{6}{|c|}{ Females } \\
\hline $\begin{array}{l}\text { First } 7 \text { years } \\
\text { After } 7 \text {, }\end{array}$ & . & $\begin{array}{l}\ldots \\
\ldots\end{array}$ & $\begin{array}{l}\ldots \\
\cdots\end{array}$ & $\stackrel{0}{(1)^{*}}$ & $\begin{array}{l}1 \cdot 1 \\
1.2\end{array}$ \\
\hline & Total & $\ldots$ & $\ldots$ & $(1)^{*}$ & $2 \cdot 3$ \\
\hline & Grand & total & $\ldots$ & $10 t$ & $6 \cdot 3$ \\
\hline
\end{tabular}

* Possibly died of cancer; diagnosis in doubt. + Includes one doutbful case.

The findings should be evaluated in relation to the hypothesis which led to this study.

Most broadly stated, we were concerned with the hypothesis that "exposure to isoniazid increases the death rates from cancer." In this hypothesis, sex, length of time since first exposure, and site of cancer are ignored. Thus we should examine the grand totals for males and females combined as shown on the last line of Table IV. Altogether, eight of the subjects definitely died of cancer, one probably died of cancer, and one possibly died of cancer, whereas 6.3 were expected to die of cancer under the alternative or null hypothesis. Even assuming that all 10 deaths were due to cancer, the difference between observed and expected numbers is not statistically significant at the 0.05 level of confidence.

If isoniazid is carcinogenic for human beings and if it acts in the same way as most known carcinogenic chemicals, then one would expect no cancers to result within the first 10 years or so after initial exposure but some to result at a later date. Of the nine men who died of cancer (including the somewhat uncertain case), one died in less than 5 years after initial exposure, six died between 5 and 10 years from first exposure, two died in the 11th year, and none died between the 12th and 15 th years (see Tables III and IV).

Of the 10 subjects who died of cancer (including the "probable" and "possible" cases) half had been treated with isoniazid for less than two years, and half for over two years. This gives no suggestion of a dose/response relationship.

The three subjects who definitely died of lung cancer, the one who probably died of lung cancer, and the two who died of cancer of the larynx and cancer of the pharynx were all cigarette smokers. The smoking habits of the 311 subjects as a group did not differ greatly from the smoking habits of American men and women of the same ages.

For male subjects there were eight definite and one probable cancer deaths with only 4.0 expected, while for female subjects there was one possible cancer death with 2.3 expected. This difference between male and female subjects, being based on very small numbers, may be fortuitous.

Taken as a whole, the evidence from this relatively small study gives no support to the hypothesis that isoniazid at a dose level of $4 \mathrm{mg}$. per $\mathrm{kg}$. of body weight per day is sufficient in itself to cause cancer in human beings within about 15 years from first exposure.

\section{Pregnant Women}

Between 4 March 1953 and 26 April 1966502 pregnant women who attended the maternity clinic of the Mount Sinai Hospital were found to have tuberculosis and were treated with isoniazid. The usual daily dosage was $4 \mathrm{mg}$. per $\mathrm{kg}$. of body weight a day, and some of the mothers were so treated during more than one pregnancy (Selikoff and Dorfmann, 1965). The percentage of women attending and the number of weeks of treatment during the course of individual pregnancies were: $14.9 \%$ for less than 4 weeks ; $33.1 \%, 4$ to 8 weeks; $29.2 \%$, 8 to 12 weeks ; $7.9 \%, 12$ to 14 weeks ; $6.9 \%, 15$ weeks or more (but not full term); and $8.0 \%$ full term. There were 54 pregnancies involving 50 mothers under isoniazid therapy at the time of conception. Complete records of isoniazid therapy previous to the first admission to the clinic are not available.

Tracing was started in the spring of 1966, and for purposes of this report we have used 1 June 1966 as the cut-off date. Of the 502 mothers, none had died of cancer; one had died of malignant hypertension; 472 were alive; 16 were traced alive for some time after leaving the hospital, but not traced in 1966 ; and 13 could not be traced. For the 489 traced women, the lapsed time between first "isoniazid pregnancy" and 1 June 1966 (or the date last traced, or the date of death in the case of one woman) was: 33 women less than 1 year; 42 women $1-2$ years; 57 women $2-4$ years ; 75 women $4-6$ years ; 59 women $6-8$ years ; 95 women $8-10$ years ; 103 women $10-12$ years ; and 25 women $12-13$ years.

\section{In-utero Exposure}

Since isoniazid is readily diffusible through all tissues (Barclay, Ebert, LeRoy, Manthei, and Roth, 1953), babies carried by the women described above were exposed to isoniazid in utero. A total of 677 babies were so exposed ; 2 were aborted, 
6 were stillborn, 4 died within less than one month after birth, and 665 lived. This compares favourably with the general maternity experience in the Mount Sinai Hospital during the same period of time. No evidence of neoplasia was found in any of the 12 aborted, stillborn, and early deaths.

Of the 665 babies who lived, $644(96.8 \%)$ were successfully traced in the spring of 1966,16 were traced for some time after birth but were not found in 1966, and 5 were never traced after initial discharge from the hospital. Of the 660 traced children at time of last report, 45 were less than 1 year of age, 53 were 1 to 2 years; 84 were 2 to 4 years; 112 were 4 to 6 years; 95 were 6 to 8 years; 132 were 8 to 10 years; 114 were 10 to 12 years; and 25 were 12 to 13 years.

All of the 660 children were alive at the date of last tracing and, so far as we know, none had cancer or any malady suggestive of cancer. One was a mongoloid and one was described as a "slow baby."

On the basis of data from the cancer registry of New York State, no more than one case of cancer would have been expected to occur among the 665 children studied, taking their age distribution into consideration. Apparently, none happened to occur.

\section{Discussion}

A number of investigators have found that oral or parenteral administration of isoniazid in large amounts causes neoplasia in the lungs and some other organs, as well as leukaemia, in certain strains of mice (Biancifiori and Severi, 1966). Published reports often indicate the dosage used in milligrams per animal of average weight; in some instances the dosage is given in mg. per kg. per day. If the doses in all reported experiments are expressed in mg. $/ \mathrm{kg}$., it appears that a daily dosage in the order of $100 \mathrm{mg}$. per $\mathrm{kg}$. of body weight is required to produce a high yield of tumour in susceptible animals. A reduction in dosage results in a lower tumour yield (Mori, Yasuno, and Matsumoto, 1960). Furthermore, even the high dosage of isoniazid failed to produce a statistically significant number of pulmonary tumours (predominantly adenomas) in some mouse strains or in other animal species tested (Peacock and Peacock, 1966 ; Viallier and Casanova, 1960).

It is hazardous to assume that findings in experimental animals apply to human beings; but if assumptions are made, then dosage must be taken into consideration. If animal experiments suggest that a very high dosage of isoniazid may produce cancer in human beings, they likewise suggest that the low dosage ( $4 \mathrm{mg}$. per $\mathrm{kg}$. of body weight) therapeutically used in the treatment of tuberculosis would be insufficient to do so.

Some carcinogenic agents are highly active when administered in utero, and this must be taken into consideration (Druckrey et al., 1966). A dosage of $4 \mathrm{mg}$. of isoniazid per $\mathrm{kg}$. of body weight is also used in treatment for tuberculosis in pregnancy, and babies carried by pregnant women with tuberculosis may receive approximately this dosage in utero.

The findings in our study were completely negative with respect to the hypothesis that in-utero exposure to isoniazid may result in the occurrence of cancer during early childhood.
They were also negative with respect to the hypothesis that isoniazid therapy for tuberculosis may result in the occurrence of cancer in women within about 10 to 15 years after the beginning of therapy, whether or not they are treated while pregnant.

Among male tuberculosis patients treated with isoniazid, and traced for 10 to nearly 15 years thereafter, there were slightly more deaths from cancer than might have been expected on the basis of general mortality statistics. However, the number of such deaths was too small to be more than slightly suggestive, there was no indication of a dose-response relationship, and the time of occurrence of the cancers (in relation to start of isoniazid therapy) was not what one would have expected if isoniazid alone was responsible. For these reasons we regard the findings in males as essentially negative.

Our investigation, particularly in respect of men, suffers from the fact that the series was rather small for epidemiological evaluation. Therefore we hope that other investigators will study the problem. Furthermore, as less than 16 years have elapsed since human beings were first exposed to isoniazid, we were unable to test the hypothesis that exposure to isoniazid may result in the occurrence of cancer after a lapse of 20 years or more from the onset of exposure. We are of the opinion that long-term studies should be undertaken to test this last hypothesis.

\section{Summary}

It having been reported that isoniazid can cause neoplasia in mice, we traced three groups of people who had received isoniazid. Firstly, 311 tuberculosis patients first so treated between 1951 and 1956 ; secondly, 502 women so treated for tuberculosis during one or more pregnancies; and, thirdly, 660 children exposed to isoniazid in utero during these pregnancies, the oldest of the children now being aged 13 years. The findings give no indication that isoniazid in daily doses of $4 \mathrm{mg}$. per $\mathrm{kg}$. of body weight increases the risk of cancer occurring in human beings within a period of 10 to 15 years after starting treatment.

\section{REFERENCES}

Barclay, W. R., Ebert, R. H., LeRoy, G. V., Manthei, R. W., and Roth, L. J. (1953). F. Amer. med. Ass., 151, 1384.

Biancifiori, C., and Severi, L. (1966). Brit. $\mathcal{F}$. Cancer, 20, 528.

Druckrey, H., Ivanković, S., and Preussmann, R. (1966). Nature (Lond.), 210, 1378 .

Ferber, B., Handy, V. H., Gerhardt, P. R., and Solomon, B. A. (1962). Cancer in New York State, Exclusive of New York City, 1941-60. A review of incidence, mortality, probability and survivorship. Bureau of Cancer Control, New York State Department of Health. Hammond, E. C. (1964a). Amer. F. publ. Hlth, 54, 11.

Hammond, E. C. (1964b). 7 . Cancer Inst., 32, 1161 .

Lancet, 1966, 2, 1452.

Mori, K., Yasuno, A., and Matsumoto, K. (1960). Gann, 51, 83.

Peacock, A., and Peacock, P. R. (1966). Brit. F. Cancer, 20, 307

Roe, F. J. C., Boyland, E., and Haddow, A. (1965). Brit. med. 7., 1, 1550 Selikoff, I. J., and Dorfmann, H. E. (1965). In J. J. Rovinsky and A F. Guttmacher's Medical, Surgical and Gynecologic Complications of Pregnancy, 2nd ed., pp. 111-143. Baltimore.

Robitzek, E. H., and Ornstein, G. G. (1952). Quart. Bull. Sea View Hosp., 13, 17 .

Viallier, J., and Casanova, F. (1960). C.R. Soc. Biol. (Paris), 154, 985. 